\title{
SELECTION OF THE GENERAL CONTRACTOR USING THE AHP METHOD
}

\section{KSIĄŻEK ${ }^{1}$, P. CIECHOWICZ ${ }^{2}$}

\begin{abstract}
The topic of this paper is the description of the General Contractor Selection procedure using the AHP method. Another aim of this paper - within the scope of decision-making - is the determination of the potential General Contractor's evaluation criteria and the selection of the best Bidder using the AHP method. We included the description of the conducted tender proceeding for the purpose of the procurement's subject. As the decisionmaking options, we adopted four construction companies that submitted their bid. A key element of the studies was the paired comparison of all hierarchical structure elements. We estimated the local weighting coefficients and global priorities of particular decision-making options as well as analysed the vulnerabilities of the obtained results.
\end{abstract}

Keywords: tender, General Contractor, AHP, decision-making

\section{INTRODUCTION}

Selection of a solid General Contractor for the subject of the procurement, that will fulfil the Investor's requirements is an important stage of an investment process. A diligently conducted tender proceeding allows minimising the risk of selecting an inadequate contractor and avoiding many various problems which may occur during the execution of the subject investment. The most popular criterion of price in a tender proceeding does not allow the decision-maker to make a reliable decision.

\footnotetext{
${ }^{1}$ PhD., Eng., Warsaw University of Technology, Faculty of Civil Engineering, Al. Armii Ludowej 16, 00-637 Warsaw, Poland, e-mail: mariola.ksiazek@il.pw.edu.pl

${ }^{2}$ MSc., Eng., student at Warsaw University of Technology, Faculty of Civil Engineering, Al. Armii Ludowej 16, 00-637 Warsaw, Poland
} 
There are many decision-making methods which can be applied in construction [2], [3], [5], [8], [9], [10], [12], [13], [14], [15]. The paper describes the procedure of selecting the General Contractor [1] using the AHP method. The aim of this paper was to determine the potential General Contractor's evaluation criteria and the selection of the best Bidder using the AHP method [11]. We included the description of the conducted tender proceeding for the purpose of the procurement's subject. As the decision-making options, we adopted four construction companies that submitted their bid. A key element of the studies was the paired comparison of all hierarchical structure elements.

\section{TENDER PROCEEDING DESCRIPTION}

Selection of the General Contractor is an important element of any investment process. The correct execution of the tender proceeding and making a thought-out choice, based on a thorough analysis of the Bidders, will help to eliminate many threats during the project execution stage. The most commonly used tender proceedings in the private sector available to a Client when selecting the General Contractor, in principle from among well-known and trusted companies (e.g. from previous projects), include:

1. Notice of open tender for construction works (e.g. in the press or Internet).

2. Submission of a request to the interested companies and, by way of pre-qualification, selection of those companies which will be invited to participate in the tender (two-stage tender).

3. Submission of a request for quotation to the selected companies and invitation to participate in the tender (one-stage tender).

It is worth to remember that the selection of the General Contractor based only on the lowest price criterion may cause threats which can impact the execution of the investment. Therefore, it is worth to broaden the Client's bid evaluation by additional criteria, such as:

1. The Bidder's financial situation.

2. Method of payment.

3. Experience in execution of similar structures.

4. Time of the procurement subject's execution.

5. Ongoing judicial disputes.

and apply one of the decision-making methods - e.g. the AHP method. 
The last stage of a tender proceeding is the conclusion of an agreement with the Contractor for the procurement subject. The tender proceeding presented above is obviously only a scheme to follow when selecting the General Contractor. In reality, each stage may be modified and broadened freely.

\section{AHP METHOD DESCRIPTION}

The Analytic Hierarchy Process was developed by the American mathematician Thomas L. Saaty. It is based on presenting the decision-making problem in the form of a hierarchical structure. AHP method stages [8]:

1. Development of a decision-making model which allows collecting all factors affecting the decision-making purpose in one place. It is the most creative stage of the AHP and it requires engaging a lot of time and resources.

2. The evaluation of the decision-making options based on comparing all elements pairs using Saaty's fundamental, nine-degree scale.

3. Estimation of values of the weighting coefficients.

4. Verification of compliance of each comparison matrix using the special consistency ratio (CR).

5. Selection of the best option

The decision-maker's preferences are determined using the relative numerical evaluations of the significance of criteria and options. The description of the AHP method is presented in author's papers [3], [4], [5], [6].

\section{RESULTS OF THE STUDY}

\subsection{SURVEY STUDIES, DECISION-MAKING CRITERIA AND OPTIONS}

In order to evaluate the options and obtain the most reliable results of the decision-making analysis, we conducted survey studies on a group of interviewees - experts, belonging to various branches of the construction sector. The group of decision-makers was selected in a thought-out way to ensure the highest reliability of the obtained results of option evaluation. Each of the evaluators possessed the content-related knowledge and experience in terms of conducting a tender proceeding for the selection of the General Contractor. The survey studies included participation of 30 decision-makers. The interviewees (experts in the field of construction) were asked to analyse 
and compare in pairs all elements of the decision-making model using Saaty's nine-degree comparison scale [16]. Each decision-maker provided answers to the questions included in the survey in the presence of a moderator, the task of whom was to specify the decision-making options evaluation procedure in the scope of the AHP method (if the method was not known) and to motivate the interviewees to provide reliable answers.

The following main decision-making criteria were adopted (specification in table 1):

1. Price - the lump sum value proposed by the Bidder in its bid, related to the total cost of execution of the subject investment;

2. Time of execution - the time of execution of the procurement subject;

3. Method of payment - amount of advanced payment, method of settlement of the other contract amount and times of payments;

4. Bidder's financial liquidity - the Bidder's ability to fulfil (repay) in due time the most chargeable (short-term) liabilities (e.g. related to the payment to business partners for products and services, payment of remuneration, etc.);

5. Experience - specification of investments executed by the Bidder, similar to our investment in terms of nature and size. Copies of reference letters provided by previous clients.

The information included in particular survey questionnaires filled out by the evaluators has undergone in-depth analysis and its interpretation was recorded in the form of comparison matrices. The information included in particular survey questionnaires filled out by the evaluators has undergone in-depth analysis and its interpretation is presented in the comparison matrices included in tables $2-5$.

\section{2. "EXPERIENCE" CRITERION CALCULATIONS - EXAMPLE}

In order to determine the Bidder constituting the best decision-making option when selecting the General Contractor for the subject investment, it is necessary to calculate the priority product in relation to the adopted criteria and the degrees of their significance. Table 6 presents the synthetic values of global priorities and the results of evaluation of the analysed options. 
Table 1. Specification of bids with indication of the selected criteria

\begin{tabular}{|c|c|c|c|c|}
\hline \multirow{2}{*}{ Criterion } & \multicolumn{4}{|c|}{ Option } \\
\hline & Bidder A & Bidder C & Bidder F & Bidder $\mathrm{G}$ \\
\hline Price & PLN 5,500,000.00 & PLN 7,543,690.00 & PLN 5,600,000.00 & PLN 6,610,824.86 \\
\hline $\begin{array}{l}\text { Time of } \\
\text { execution }\end{array}$ & 17 weeks & 17 weeks & 14 weeks & 16 weeks \\
\hline \multirow{3}{*}{$\begin{array}{l}\text { Method of } \\
\text { payment }\end{array}$} & $\begin{array}{l}30 \% \text { of advanced } \\
\text { payment in relation to } \\
\text { the total bid amount } \\
\text { within } 7 \text { days from the } \\
\text { date of Agreement } \\
\text { conclusion based on a } \\
\text { VAT invoice }-7 \text {-day } \\
\text { time of payment. }\end{array}$ & $\begin{array}{l}50 \% \text { of advanced } \\
\text { payment in relation to } \\
\text { the total bid amount } \\
\text { within } 7 \text { days from the } \\
\text { date of Agreement } \\
\text { conclusion based on a } \\
\text { VAT invoice - } 7 \text {-day } \\
\text { time of payment. }\end{array}$ & $\begin{array}{l}70 \% \text { of advanced } \\
\text { payment in relation to } \\
\text { the total bid amount } \\
\text { within } 5 \text { days from the } \\
\text { date of Agreement } \\
\text { conclusion based on a } \\
\text { VAT invoice - 7-day } \\
\text { time of payment. }\end{array}$ & $\begin{array}{l}20 \% \text { of advanced } \\
\text { payment in relation to } \\
\text { the total bid amount } \\
\text { within } 7 \text { days from the } \\
\text { date of Agreement } \\
\text { conclusion based on a } \\
\text { VAT invoice }-7 \text {-day } \\
\text { time of payment. }\end{array}$ \\
\hline & $\begin{array}{l}\text { Settlement of the other } \\
\text { amount in accordance } \\
\text { with the monthly } \\
\text { settlement in even } \\
\text { amounts, whereas the } \\
\text { last payment in the } \\
\text { amount of } 20 \% \text { will be } \\
\text { settled within } 21 \text { days } \\
\text { from the date of } \\
\text { conclusion of the works. }\end{array}$ & $\begin{array}{l}\text { Settlement of the } \\
\text { other amount in } \\
\text { accordance with the } \\
\text { monthly settlement in } \\
\text { even amounts, within } \\
14 \text { days from the date } \\
\text { of invoice issue. }\end{array}$ & $\begin{array}{l}\text { Settlement of the other } \\
\text { amount in accordance } \\
\text { with the monthly } \\
\text { settlement in even } \\
\text { amounts, whereas the } \\
\text { last payment will be } \\
\text { settled within } 14 \text { days } \\
\text { from the date of issue } \\
\text { of the last invoice. }\end{array}$ & $\begin{array}{l}\text { Settlement of the other } \\
\text { amount in accordance } \\
\text { with the monthly } \\
\text { settlement in even } \\
\text { amounts, whereas the } \\
\text { last payment in the } \\
\text { amount of } 20 \% \text { will be } \\
\text { settled within } 21 \text { days } \\
\text { from the date of } \\
\text { conclusion of the works. }\end{array}$ \\
\hline & $\begin{array}{l}\text { Invoice payment dates } \\
-21 \text { days. }\end{array}$ & $\begin{array}{l}\text { Invoice payment dates } \\
-21 \text { days. }\end{array}$ & $\begin{array}{l}\text { Invoice payment dates } \\
-21 \text { days. }\end{array}$ & $\begin{array}{l}\text { Invoice payment dates } \\
-21 \text { days. }\end{array}$ \\
\hline $\begin{array}{c}\text { Current } \\
\text { ratio }(\mathrm{CR})\end{array}$ & 1.08 & 1.37 & 1.81 & 0.78 \\
\hline $\begin{array}{c}\text { Quick ratio } \\
(\mathrm{QR})\end{array}$ & 0.64 & 1.09 & 1.18 & 0.52 \\
\hline $\begin{array}{l}\text { Instant } \\
\text { ratio }\end{array}$ & 0.48 & 0.78 & 0.98 & 0.34 \\
\hline Experience & $\begin{array}{l}\text { The Bidder provided } 3 \\
\text { reference letters } \\
\text { confirming the execution } \\
\text { of structures similar to } \\
\text { the procurement subject }\end{array}$ & $\begin{array}{l}\text { The Bidder provided } \\
7 \text { reference letters } \\
\text { confirming the } \\
\text { execution of } \\
\text { structures similar to } \\
\text { the procurement } \\
\text { subject }\end{array}$ & $\begin{array}{l}\text { The Bidder provided } 5 \\
\text { reference letters } \\
\text { confirming the } \\
\text { execution of structures } \\
\text { similar to the } \\
\text { procurement subject }\end{array}$ & $\begin{array}{l}\text { The Bidder provided } 4 \\
\text { reference letters } \\
\text { confirming the execution } \\
\text { of structures similar to } \\
\text { the procurement subject }\end{array}$ \\
\hline
\end{tabular}

Table 2. Comparison of the criteria with the purpose and the weighting coefficients

\begin{tabular}{|c|c|c|c|c|c|}
\hline CRITERION & Price & $\begin{array}{l}\text { Time of } \\
\text { execution }\end{array}$ & $\begin{array}{l}\text { Method of } \\
\text { payment }\end{array}$ & $\begin{array}{l}\text { Bidder's } \\
\text { financial } \\
\text { liquidity }\end{array}$ & Experience \\
\hline Price & 1 & 4 & 5 & 8 & 6 \\
\hline Time of execution & $1 / 4$ & 1 & 4 & 6 & 5 \\
\hline Method of payment & $1 / 5$ & $1 / 4$ & 1 & 4 & 3 \\
\hline $\begin{array}{c}\text { Bidder's financial } \\
\text { liquidity }\end{array}$ & $1 / 8$ & $1 / 6$ & $1 / 5$ & 1 & $1 / 3$ \\
\hline Experience & $1 / 6$ & $1 / 5$ & $1 / 3$ & 3 & 1 \\
\hline TOTAL: & 1.74 & 5.62 & 10.58 & 22.00 & 15.33 \\
\hline
\end{tabular}


Table 3. Comparison of options in relation to the EXPERIENCE criterion

\begin{tabular}{|c|c|c|c|c|}
\hline EXPERIENCE & Bidder A & Bidder C & Bidder F & Bidder G \\
\hline Bidder A & 1 & $1 / 7$ & $1 / 5$ & $1 / 3$ \\
\hline Bidder C & 7 & 1 & 3 & 5 \\
\hline Bidder F & 5 & $1 / 3$ & 1 & 2 \\
\hline Bidder G & 3 & $1 / 5$ & $1 / 2$ & 1 \\
\hline TOTAL: & 16.00 & 1.68 & 4.70 & 8.33 \\
\hline
\end{tabular}

Table 4. Solution matrix normalisation

\begin{tabular}{|c|c|c|c|c|}
\hline EXPERIENCE & Bidder A & Bidder C & Bidder F & Bidder G \\
\hline Bidder A & 0.06 & 0.09 & 0.04 & 0.04 \\
\hline Bidder C & 0.44 & 0.60 & 0.64 & 0.60 \\
\hline Bidder F & 0.31 & 0.20 & 0.21 & 0.24 \\
\hline Bidder G & 0.19 & 0.12 & 0.11 & 0.12 \\
\hline
\end{tabular}

Table 5. Weighting coefficients for the Options

\begin{tabular}{|c|c|c|}
\hline CRITERION & WEIGHTS & WEIGHTS [\%] \\
\hline Price & 0.50 & $50.27 \%$ \\
\hline Time of execution & 0.26 & $25.97 \%$ \\
\hline Method of payment & 0.13 & $12.63 \%$ \\
\hline Bidder's financial liquidity & 0.04 & $3.85 \%$ \\
\hline Experience & 0.07 & $7.29 \%$ \\
\hline
\end{tabular}

Table 6. Weighting coefficients for the Options in relation to the Experience criterion

\begin{tabular}{|c|c|c|}
\hline EXPERIENCE & WEIGHTS & $\begin{array}{c}\text { WEIGHTS } \\
{[\%]}\end{array}$ \\
\hline Bidder A & 0.06 & $5.76 \%$ \\
\hline Bidder C & 0.57 & $56.81 \%$ \\
\hline Bidder F & 0.24 & $24.10 \%$ \\
\hline Bidder G & 0.13 & $13.33 \%$ \\
\hline
\end{tabular}

Based on the above table, it may be assumed that due to the "experience" criterion", Bidder C is the best, while Bidder $\mathrm{A}$ is the worst.

In order to determine the Bidder constituting the best decision-making option when selecting the General Contractor for the subject investment, it is necessary to calculate the priority product in relation to the adopted criteria and the degrees of their significance. Tables 7 and 8 present the synthetic values of global priorities and the results of evaluation of the analysed options.

Table 7. Specification of the options' relative evaluations

\begin{tabular}{|c|c|c|c|c|c|}
\hline & Price & $\begin{array}{c}\text { Time of } \\
\text { execution }\end{array}$ & $\begin{array}{c}\text { Method of } \\
\text { payment }\end{array}$ & $\begin{array}{c}\text { Bidder's } \\
\text { financial } \\
\text { liquidity }\end{array}$ & Experience \\
\hline Bidder A & $51.54 \%$ & $7.21 \%$ & $33.12 \%$ & $10.99 \%$ & $5.76 \%$ \\
\hline Bidder C & $4.18 \%$ & $7.21 \%$ & $12.26 \%$ & $28.09 \%$ & $56.81 \%$ \\
\hline Bidder F & $32.71 \%$ & $62.98 \%$ & $4.92 \%$ & $56.64 \%$ & $24.10 \%$ \\
\hline Bidder G & $11.57 \%$ & $22.60 \%$ & $49.71 \%$ & $4.28 \%$ & $13.33 \%$ \\
\hline
\end{tabular}


Table 8. Global priorities and synthetic results

\begin{tabular}{|c|c|c|c|c|c|c|}
\hline & Price & $\begin{array}{c}\text { Time of } \\
\text { execution }\end{array}$ & $\begin{array}{c}\text { Method of } \\
\text { payment }\end{array}$ & $\begin{array}{c}\text { Bidder's } \\
\text { financial } \\
\text { liquidity }\end{array}$ & Experience & \multirow{2}{*}{ TOTAL: } \\
\cline { 1 - 5 } $\begin{array}{c}\text { Criteria } \\
\text { weights }\end{array}$ & $50.27 \%$ & $25.97 \%$ & $12.63 \%$ & $3.85 \%$ & $7.29 \%$ & \\
\hline Bidder A & $25.91 \%$ & $1.87 \%$ & $4.18 \%$ & $0.42 \%$ & $0.42 \%$ & $32.81 \%$ \\
\hline Bidder C & $2.10 \%$ & $1.87 \%$ & $1.55 \%$ & $1.08 \%$ & $4.14 \%$ & $10.74 \%$ \\
\hline Bidder F & $16.44 \%$ & $16.35 \%$ & $0.62 \%$ & $2.18 \%$ & $1.76 \%$ & $37.35 \%$ \\
\hline Bidder G & $5.82 \%$ & $5.87 \%$ & $6.28 \%$ & $0.16 \%$ & $0.97 \%$ & $19.10 \%$ \\
\hline
\end{tabular}

\subsection{VERIFICATION OF THE OBTAINED RESULTS}

The next stage of evaluation of the decision-making options is the verification of the obtained results - a content-related and formal evaluation, which allows eliminating the least beneficial options in the light of the adopted criteria and selection of the options that correspond mostly to the decision-maker's preferences. The content-related verification is based on checking whether the obtained results and reasonable and compliant with the projected reality [4], [6], [7]. In contrast, formal verification is based on checking whether the options paired comparison matrices subject to analysis are not internally inconsistent. For this purpose, we use a measure called the consistency ratio (CR). According to the assumptions of the AHP method, if the consistency ratio exceeds $10 \%$, the obtained solutions evaluation results must be rejected as inconsistent. The inconsistency $(\mathrm{CR}>10 \%)$ may result from many reasons, such as: experts' incompetence, excessive quantity of information, incorrect hierarchical structure, altering environment, nature of the studied reality fragment. If the $\mathrm{CR}$ value is smaller or equal to 0.1 , it is assumed that the consistency of the elements comparison is satisfactory. In any other case, it is necessary to correct the preferences, repeatedly compare the significance of subsequent object pairs, development of a new comparison matrix A, i.e. conducting a new initial fragment of the calculation procedure. For the EXPERIENCE criterion, the calculations are as follows:

$$
\begin{gathered}
\lambda_{\text {max }}=4,08 \\
C I=\frac{\lambda_{\text {max }}-n}{R I(n-1)}=\frac{4,08-4}{0,89(4-1)}=2,92 \%<10 \%
\end{gathered}
$$

The CR value for the analysed matrix amounts to $2.92 \%$ (result below $10 \%$ ), which means that the matrix is consistent and logical. 


\section{CONCLUSIONS}

The multicriteria evaluation of the decision-making options based on the AHP method clearly demonstrated the pros and cons of all Bidders. Based on the obtained results, we have selected the most beneficial bid in the light of the adopted criteria and interviewee preferences. The correct execution of the tender proceeding for the selection of the General Contractor is a very important element of any investment process. It allows minimising the risk of selecting an inadequate contractor and avoiding many various problems which may occur during the execution of the subject investment.

As result of the conducted evaluation of the decision-making options using the AHP method, we concluded that the best and most popular criterion of selection of the General Contractor is the price $(57.27 \%)$ and the least important - the bidder's financial liquidity (3.85\%).

The obtained information constitutes a solid basis for the selection of the General Contractor, but linking and analysing all aspects is not easy and thus it is worth to use one of the multicriteria analysis methods for evaluating the options, e.g. the AHP method. This will allow the decisionmaker to align the decision-making reality and sort the options in question.

Furthermore, as result of the evaluation of the decision-making options using the AHP method it was concluded that the best solution is to select Bidder F (37.35\%), which was confirmed by the competitive price for work execution, shortest time of execution, stable financial situation and proper experience. A negative aspect of selecting the above option is the worst method of payment for executed works proposed by the Bidder. An alternative option, with a slightly worse selection coefficient (32.81\%), is Bidder A, the bid of which was characterised by the lowest price and good method of payment (important criteria for the interviewees). However, this choice would mean a longer time of investment execution and the above Bidder is characterised with bad financial liquidity and the least experience in the execution of similar investments.

The Analytic Hierarchy Process method is very versatile, flexible and universal, because it accounts for the specificity of psychological valuation processes, which are most of all of a relational and hierarchical nature. The numerous applications of this method in supporting various decisionmaking processes (e.g. technical, economic or social) confirm its usefulness, especially in cases where most of the evaluation criteria is qualitative and the decision-maker's experience constitutes the main source of evaluations, which are subjective. Limitation of calculations in the AHP method to linear algebra and vector calculus facilitates computer implementation and allows using the method in practice. 


\section{REFERENCES}

1. N. Ibadov, "Contractor selection for construction project, with the use of fuzzy preference relation", XXIV RS-P seminar, Theoretical Foundation of Civil Engineering, Elsevier Ltd. Procedia Engineering 111 (2015) pp. $317-323$.

2. N. Ibadov, "Wybór dostawcy w przedsięwzięciach budowlanych na podstawie rozmytej relacji preferencji”, Logistyka 3/2015, Pełny tekst na CD1 str. 1823-1829.

3. M. Krzemiński, M. Książek, "Ocena jakości wybranych obiektów budowlanych metodą punktu idealnego", Inżynieria i Budownictwo, nr 12 / 2007.

4. M. Książek, "Wielokryterialna ocena rozwiązań projektowych budynków”, Rozprawa doktorska, Wydawnictwa Politechniki Warszawskiej, Warszawa 2010.

5. M. Książek. P. Nowak, "Expert methods for design solutions assessment", Logistyka 2009, nr 6.

6. M. Książek, "Wykorzystanie systemu informatycznego w procesie decyzyjnym”, Logistyka 2010, nr 6.

7. M. Książek: Wykorzystanie wybranych metod wielokryterialnych do oceny inwestycji w procesie decyzyjnym. Logistyka 2011, nr 3;

8. M. Książek, P. Nowak, J. Rosłon, "Choice of investment variant for roads safety improvement", Logistyka 2014, nr 2.

9. M. Książek, P. Nowak, S. Kivrak, J. Rosłon, L. Ustinovichius, "Computer-aided decision-making in construction project development", Journal of Civil Engineering and Management, 2015, vol. 21 (2), pages: 248-259, ISSN 1392-3730.

10. M. Książek, P. Nowak, J. Rosłon, T. Wieczorek, "Multicriteria Assessment of Selected Solutions for the Building Structural Walls“, XXIII R-S-P seminar, Theoretical Foundation of Civil Engineering (23RSP), Procedia Engineering, 2014, vol. 91, pages: 406-411, ISSN: 1877-7058.

11. J. Rosłon, "Zastosowanie wybranych metod kwalifikacji podczas doboru wykonawców infrastrukturalnych projektów budowlanych”, TTS Technika Transportu Szynowego, 10/ 2013.

12. Radziszewska-Zielina E., Szewczyk B., "Controlling partnering relations in construction operations using fuzzy reasoning”, „Archives of Civil Engineering”, vol. LXI, is. 3, 2015, pp. 89-104.

13. Radziszewska-Zielina E., "Fuzzy control of the partnering relations of a construction enterprise", Journal of Civil Engineering and Management, Vol. 17, No. 1, 2011, pp. 5-15.

14. Radziszewska-Zielina E., "Analysis of the partnering relations of Polish", Slovak and Ukrainian construction enterprises, „Technological and Economic Development of Economy”, Vol. 16, No. 3, 2010, pp. $432-454$.

15. Radziszewska-Zielina E., "Analysis of the Impact of the Level of Partnering Relations on the Selected Indexes of Success of Polish Construction Enterprises”, „Inzinerine Ekonomika-Engineering Economics”, Vol. 21, No. 3, 2010, pp. 324-335

16. T. L. Saaty, "The Analytic Hierarchy Process", RWS Publications, Pittsburgh 1996.

Received 15. 09. 2015

Revised 24. 10. 2015 


\section{LIST OF FIGURES AND TABLES:}

Tab. 1. Zestawienie ofert ze wskazaniem wybranych kryteriów

Tab. 2. Porównanie kryteriów względem celu wraz ze współczynnikami wagowymi

Tab. 3. Porównanie wariantów względem kryterium - DOŚWIADCZENIE

Tab. 4. Normalizacja macierzy rozwiązań

Tab. 5. Współczynniki wagowe dla Wariantów

Tab. 6. Współczynniki wagowe dla Wariantów względem kryterium - doświadczenie

Tab. 7. Zestawienie relatywnych ocen wariantów

Tab. 8. Priorytety globalne i wyniki syntetyczne

Tab. 1. Specification of bids with indication of the selected criteria

Tab. 2. Comparison of the criteria with the purpose and the weighting coefficients

Tab. 3. Comparison of options in relation to the EXPERIENCE criterion

Tab. 4. Solution matrix normalisation

Tab. 5. Weighting coefficients for the Options

Tab. 6. Weighting coefficients for the Options in relation to the Experience criterion

Tab. 7. Specification of the options' relative evaluations

Tab. 8. Global priorities and synthetic results 


\section{WYBÓR GENERALNEGO WYKONAWCY PRZY WYKORZYSTANIU METODY AHP}

Stowa kluczowe: przetarg, Generalny Wykonawca, AHP, proces decyzyjny

\section{STRESZCZENIE:}

Istotnym etapem procesu inwestycyjnego jest wybór solidnego Generalnego Wykonawcy przedmiotu zamówienia, spełniającego wymagania Inwestora. Rzetelnie przeprowadzona procedura przetargowa umożliwia zminimalizowanie ryzyka wyboru nieodpowiedniego wykonawcy oraz uniknięcie wielu, różnego typu problemów, które mogą zaistnieć $\mathrm{w}$ trakcie realizacji przedmiotowej inwestycji. Najpopularniejsze w procesie przetargowym kryterium ceny, nie pozwala decydentowi podjąć wiarygodnej decyzji.

Istnieje wiele metod podejmowania decyzji, które można zastosować w budownictwie. W artykule opisano procedurę wyboru Generalnego Wykonawcy przy wykorzystaniu metody AHP. Celem pracy było ustalenie optymalnych kryteriów oceny potencjalnego Generalnego Wykonawcy oraz wybór najlepszego Oferenta przy wykorzystaniu metody AHP. Przedstawiono opis przeprowadzonego procesu przetargowego na potrzeby przedmiotu zamówienia. Jako warianty decyzyjne przyjęto cztery firmy budowlane, które złożyły ofertę. Kluczowym elementem badań było porównywanie parami wszystkich elementów struktury hierarchicznej.

W celu dokonania oceny wariantów oraz otrzymania jak najbardziej wiarygodnych wyników analizy decyzyjnej, przeprowadzono badania ankietowe na grupie respondentów - ekspertów, należących do różnych branż za zakresu budownictwa. Grupę decydentów dobrano w sposób przemyślany tak, aby zapewnić jak największą wiarygodność otrzymanych wyników oceny wariantów. Każdy z oceniających posiadał widzę merytoryczną oraz doświadczenie W zakresie przeprowadzania procesu przetargowego na wybór Generalnego Wykonawcy. Respondentów (ekspertów z zakresu budownictwa) poproszono o przeanalizowanie i porównanie parami wszystkich elementów modelu decyzyjnego przy pomocy dziewięciostopniowej skali porównań Saaty’ego. Każdy decydent udzielił odpowiedzi na pytania zawarte w ankiecie w obecności moderatora, którego zadaniem było sprecyzowanie procedury oceny wariantów decyzyjnych w ramach metody AHP (w przypadku braku jej znajomości) oraz zmotywowanie respondentów do udzielenia rzetelnych odpowiedzi.

Przyjęto następujące główne kryteria decyzyjne:

1. Cena - wartość ryczałtowa zaproponowana przez Oferenta w jego ofercie odnosząca się do całkowitego kosztu realizacji przedmiotowej inwestycji;

2. Czas realizacji - okres wykonania przedmiotu zamówieni;

3. Forma płatności - wysokość zaliczki, forma rozliczenia pozostałej kwoty kontraktu oraz terminy płatności;

4. Płynność finansowa Oferenta - zdolność Oferenta do wywiązywania się (spłacania) w terminie najbardziej wymagalnych (krótkoterminowych) zobowiązań (np. związanych z zapłatą kontrahentom za wyroby i usługi, wypłatą wynagrodzeń, itp.);

5. Doświadczenie - wykaz ukończonych realizacji Oferenta o podobnym do naszej inwestycji charakterze i wielkości. Kopie referencji udzielonych przez poprzednich klientów.

Informacje zawarte w poszczególnych kwestionariuszach ankietowych wypełnionych przez oceniających, poddano wnikliwej analizie, a ich interpretację zapisano w postaci macierzy porównań. 
W celu wskazania, który z Oferentów stanowi najlepszy wariant decyzyjny przy wyborze Generalnego Wykonawcę przedmiotowej inwestycji, obliczono iloczyny priorytetów względem przyjętych kryteriów i ich stopni ważności.

Następny etap oceny wariantów decyzyjnych stanowiła weryfikacja otrzymanych wyników - merytoryczna i formalna, która umożliwiła wyeliminowanie wariantów najmniej korzystnych w świetle przyjętych kryteriów oraz wyłonienie wariantów najbardziej odpowiadających preferencjom decydentów. Weryfikacja merytoryczna polegała na sprawdzeniu, czy uzyskane wyniki są rozsądne i zgodne z przewidywaną rzeczywistością. Wyniki niezgodne ze zdrowym rozsądkiem mogą mieć różne przyczyny np.: niepoprawnie określony cel badania, niewłaściwie zdefiniowany model hierarchiczny lub błędnie wprowadzone dane. Natomiast weryfikacja formalna, polegała na sprawdzeniu, czy poddane analizie macierze porównań wariantów parami nie są wewnętrzne sprzeczne. Wewnętrzna sprzeczność jest najczęściej określana pojęciem „niespójności”. Podejmowanie decyzji na podstawie ostatecznych wyników przy wykorzystaniu metody AHP ma sens tylko wtedy, gdy wszystkie porównania wariantów parami zostały przeprowadzone w logiczny sposób. Dlatego też, ocena zgodności otrzymanych wyników stanowi integralny, dokonywany indywidualnie dla każdej macierzy, etap analizy w ramach metody AHP. do tego celu stosuje się miernik, nazywany współczynnikiem zgodności CR (ang. Consistency Ratio). Zgodnie z założeniami metody AHP, jeżeli współczynnik CR przekracza wartość 10\% to otrzymane wyniki oceny rozwiązań należy odrzucić, jako nielogiczne. Niezgodność (współczynnik CR > 10\%) może wynikać z wielu przyczyn takich, jak: niekompetencja ekspertów, zbyt duża ilość informacji, niepoprawna struktura hierarchiczna, zmieniające się otoczenie, natura badanego fragmentu rzeczywistości. Jeżeli wartość współczynnika zgodności CI jest mniejsza, bądź równa 0,1 to przyjmuje się, iż zgodność porównań elementów jest zadowalająca. w przeciwnym wypadku - konieczne jest skorygowanie preferencji, ponowne porównanie znaczenia kolejnych par obiektów, utworzenie nowej macierzy porównań A, czyli przeprowadzenie od nowa wyjściowego fragmentu procedury obliczeniowej. Wartość współczynnika CI dla analizowanej macierzy wyniósł 2,92 \% (wynik poniżej 10\%), co oznacza, iż badana macierz jest spójna i logiczna. po przeprowadzeniu niezbędnych obliczeń dla wszystkich wariantów i kryteriów w ramach metody AHP otrzymano uszeregowanie wariantów. Ważnym elementem badań było przeprowadzenie analizy wrażliwości wyników w zależności od wartości współczynników wagowych dla poszczególnych kryteriów. Przykład analizy dla badanego przypadku, został zaprezentowany w artykule. Artykuł zwieńczony jest analizą wyników oraz wnioskami. 